\section{Science and Technology Section}

Vice-Chair/Chair-Elect: Martin Kesselman, Information Services Librarian, Library of Science and Medicine, Rutgers University, Piscataway, NJ 08855 (224); Lois M. Pausch, Assistant Mathematics Librarian, University of Illinois, Urbana, IL 61801 (199).

Secretary: Beverlee French, Head, Science and Engineering Library, University of California, San Diego, La Jolla, CA 92093 (243); Donald G. Frank, Head, Science-Engineering Library, University of Arizona, Tucson, AZ 85721 (172).

\section{Slavic and East European Section}

Vice-Chair/Chair-Elect: StePhen D. CoRrSin, Deputy Associate Librarian for Technical Services, Brooklyn College, Brooklyn, NY 11210 (31); Viveca Seymour, Serials Cataloger, Stanford University, Stanford, CA 94305 (29).

Member-at-Large: MARIE BEDNAR, Head of Bibliographic Support Services, Pennsylvania State University, University Park, PA 18602 (20); Richard L. Kort, Slavic Cataloger, Boston Public Library, Boston, MA 02117 (11); Natalia B. Bezugloff, Foreign Literature Department Head, Cleveland Public Library, Cleveland, OH 441141271 (15); David J. Norden, Library Director, Hampden-Sydney College, Hampden-Sydney, VA 23943 (13); Cecelia L. Shores, Head, Acquisitions Department, Center for Research Libraries, Chicago, IL 60637 (3).

\section{University Libraries Section}

Vice-Chair/Chair-Elect: MaXIne H. Reneker, Associate University Librarian for Public Services, Arizona State University, Tempe, AZ 85287 (859); Jordan M. Scepanski, Director, University Library and Learning Resources, California State University, Long Beach, CA 90840 (794).
Secretary: Paula D. Watson, Assistant Director of General Services, University of Illinois, Urbana, IL 61801 (848); Nancy L. Baker, Associate Director for Public Services, University of Washington, Seattle, WA 98195 (753).

\section{Western European Specialists Section}

Vice-Chair/Chair-Elect: MARTHA L. Brogan, Assistant to the Vice President for Academic Affairs, University of Minnesota, Minneapolis, MN 55455 (114); David J. Cooper, Humanities Bibliographer, Johns Hopkins University, Baltimore, MD $21218(68)$.

Secretary: Ceres B. Birkhead, Assistant Head, Serials Department, University of Utah, Salt Lake City, UT 84112 (110); Leona L. Wise, German Bibliographer, University of Southern California, Los Angeles, CA 90089-0182 (62).

Member-at-Large: Susanne F. Roberts, Humanities Bibliographer, Yale University, New Haven, CT 06520 (110); Robert G. Sewell, Coordinator of Collection Management and Development, State University of New York, Stony Brook, NY 11794-3300 (70).

\section{Women's Studies Section}

Vice-Chair/Chair-Elect: Sarah M. Pritchard, General Reading Rooms Division, Library of Congress, Washington, DC 20540 (150); write-in (4).

Recorder: DEB BIGGS, Reference/Instruction Librarian, Undergraduate Library, University of Michigan, Ann Arbor, MI 48109-1185 (105); Judith Hudson, Head, Cataloging Department, State University of New York, Albany, NY 12222 (52).

Member-at-Large: Molly MAHONY, Reference Librarian, Keene State College, Keene, NH 03431 (113); Suzy Margot Slavin, Head, Reference Department, McGill University, Montreal, Quebec, Canada H3A IYl (39).

\title{
The International Association for Social Science Informa- tion Service and Technology (IASSIST)
}

\author{
By Diane Geraci \\ Social Science Bibliographer \\ State University of New York at Binghamton
}

The International Association for Social Science Information Service and Technology (IASSIST) is an organization which brings together administrators, computer programmers, data archivists, librarians, and researchers interested in quantitative analysis. IASSIST members facilitate access to so- cial science machine-readable data files (MRDFs) as well as promote commitment to the preservation and administration of these resources.

IASSIST was formed in 1974 following the cessation of National Science Foundation funding for the Council of Social Science Data Archives and 
concomitant with the escalation of quantitative social science data generated in machine-readable form. IASSIST grew out of the need for intermediaries to increase access and manage this burgeoning arena of social science data available on magnetic tape.

While data archives have generally developed separately from conventional libraries, there has been a distinct movement in the 1980s towards greater cooperation between data archives, computer centers, and libraries. This is demonstrated by the growing number of "traditional" librarians who are active members of IASSIST, by IASSIST's involvement in developing cataloging standards for machine-readable data files, and by the number of librarians who attend the annual InterUniversity Consortium for Political and Social Research (ICPSR) representative meetings in Ann Arbor, Michigan, and handle MRDFs on college and university campuses.

This year's annual conference was held on May 26-29, 1988, in Washington, D.C. Again, the conference illustrated the convergent interests of various types of institutions who handle social science MRDFs, including traditional archives, colleges and universities, government agencies, and commercial organizations. Conference participants were drawn from all of these institutions and organizations. The program featured contributed papers, round table discussions, and workshops concerned with accessing, archiving, and using machine-readable social science data and reflected the diversity and expertise of its participants.

The four-day meeting was opened by IASSIST president Judith Rowe from Princeton University, who presided over the first plenary session, "View from the Statistical Agencies." Representatives from the Israel Central Bureau of Statistics, Statistics Canada, Statistics Sweden, and the U.S. Bureau of the Census discussed issues of accessibility, dissemination, and new products relating to government-produced data. There were two other plenary sessions: "Professional Standards in the Information Age," chaired by Thomas E. Brown, National Archives and Records Administration and incoming IASSIST president, and "Beyond the Social Science Data Archive," chaired by Carolyn L. Geda from the Inter-University Consortium for Political and Social Research.

Round table lunches provided the opportunity for informal discussions among conference participants. Topics included: complex data-sets and software to make them friendly, archival appraisal of machine-readable statistical files, management and publicity archival tools, data management technology, and training needed for data management.

The concurrent sessions were equally varied and included the following topics: the preservation and use of empirical economic data, educating the data user, spatially referenced data, microcomputerbased data products, democratization of data, con- sumer expenditure survey, Canadian general social survey, issues in integrating machine-readable records into traditional library services, statistical use of administrative records, data archive organization, data management technology, storage and I/O technologies, social policy simulation using survey microdata products, online catalogs with records of computer data files, cross-national social surveys, issues in data dissemination, and mapping as a data dissemination technique.

Five half-day workshops were also offered: "Interchange Standards," "Data Products from the Bureau of the Census," "The Data Archive on Adolescent Pregnancy and Pregnancy Prevention," "Special Aspects of the National Longitudinal Surveys of Youth," and "Integrating Machine Readable Records into Traditional Library Services." The latter workshop and concurrent session of similar title are of particular interest to academic and research libraries and illustrate an emerging dialogue between diverse groups within IASSIST on the issues involved in such an integration.

Elizabeth Stephenson, University of California at Los Angeles, organized the 31/2-hour workshop on "Integrating Machine-Readable Records into Traditional Library Services." She invited five academic librarians to conduct the workshop: Sarah Cox-Byrne, Vassar College; JoAnn Dionne, Yale University; Diane Geraci, State University of New York at Binghamton; Carson Holloway, University of North Carolina at Chapel Hill; and Jim Jacobs, University of California at San Diego. The workshop confirmed the challenge to research libraries serving social scientists of integrating statistical data files into print-oriented collections.

Topics covered during the workshop included: history of development of services at various institutions; staffing and training; financial administration; equipment; types of services; organizational arrangements between libraries, computing centers, and other research facilities; and access to tapes and codebooks. While there are inherent difficulties with handling raw data, from the physical maintenance of the magnetic tapes themselves to providing statistical consultation, workshop participants illustrated that there is no one configuration of services and collection maintenance of MRDFs that predominates in an academic setting.

Lively workshop discussions dealt with issues of providing services for MRDFs, developing collections of data sets and codebooks, broadening service points, and integrating MRDF records into online public catalogs. Questions were raised about the impact of government information being distributed in electronic format to depository libraries and the impact of CD-ROMs.

Jaia Barrett, Association of Research Libraries, chaired the concurrent session entitled, "Issues in the Integration of Machine-Readable Records into Traditional Library Services." Diverse perspectives were presented by Ann Gerken, data archivist, University of California at Berkeley; Karin 
Wittenborg, collection development librarian, University of California at Los Angeles; Donald Treiman, sociologist, University of California at Los Angeles; and Raymond Carpenter, library school faculty, University of North Carolina at Chapel Hill.

Interesting points were raised during this session on the user's perspective of how data archives are different from traditional libraries. The fact was stressed that using MRDFs requires a great deal of interaction with the user, often including technical assistance. Archives not only assist with finding the appropriate data sets but serve as repositories for researchers who want someone else to manage their files and documentation. Access to data sets at the variable level - that is, beyond broad subject, title, and principle investigator level - was also discussed.

Other remarks focused on the high degree of technical and statistical knowledge required to provide full service to MRDFs which may inhibit library involvement. Librarians need to understand codebooks and how they are used, how the data can be accessed and manipulated, and how data files relate to print sources. In the same vein, the lack of training provided in library school programs for dealing with machine-readable files was mentioned. Formal library training in this area is still unavailable although some organization and information skills are generally transferable. The question of what kinds and levels of service librarians can provide was raised.

Another perspective suggested that libraries must not segregate information by format. Libraries cannot expect patrons to know they are looking for information in machine-readable form. At the same time, there must be recognition that raw data is handled less easily. Issues of building collections of MRDFs within libraries and the requisite training to provide responsible service were considered.

The IASSIST conference provided a forum for individuals responsible for acquisition, administration, and reference services associated with social science machine-readable data files. MRDFs are a valuable and often underutilized information source for researchers and students in the social sciences. The role of MRDFs in research libraries continues to be provocative.

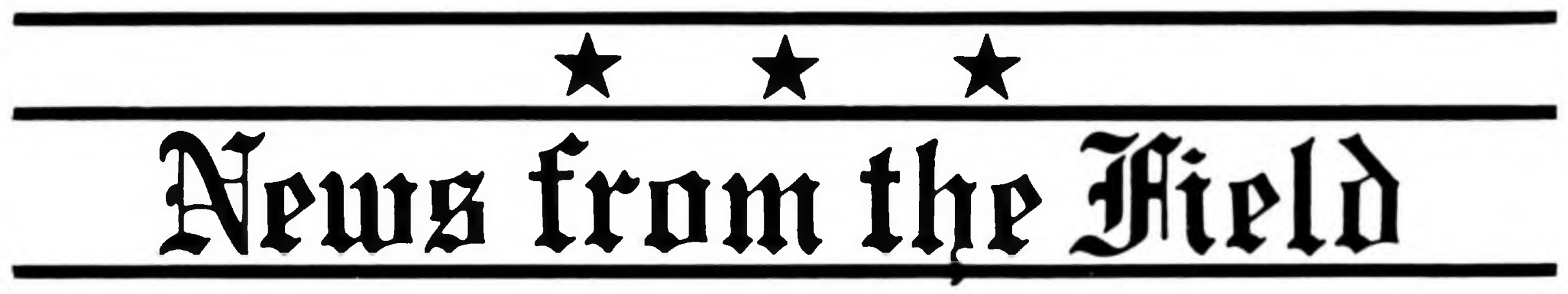

\section{Acquisitions}

- The Brown University Library, Providence, has obtained the archival records of the Gorham Division of Textron, Inc., in accordance with a "milestone agreement" reached between the two organizations. Gorham, founded in Providence by Jabez Gorham in 1831, was the predominant American manufacturer of silver in the 19th and 20th centuries, and it contains in its archives the history of an important area of American art. Measuring over 1,000 linear feet, the collection features many thousands of drawings and photographs of Gorham products. Care was taken by the company to preserve corporate, personnel, costing, sales, and advertising records, as well as blueprints, plaster casts, and copper printing plates. Textron, which acquired Gorham in 1967, is headquartered in Providence.

- George Washington University Library, Washington, D.C., has purchased 500 Yiddish books from the National Yiddish Book Center in Amherst, Massachusetts. Funding for the collection came through a grant from the National Endowment for the Humanities. The collection includes reference works, fiction, poetry, history, biography, ethnography, holocaust studies, the arts, and social and political theory. Also included is a Yiddish translation of the Hebrew Bible, as well as works by Sholom Aleichem and Sholom Asch. The books were acquired for use by faculty and students in the University's undergraduate program in Judaic studies.

- The Library of Congress has been given by the National Broadcasting Company a microform copy of one million descriptive cards constituting the NBC Television Program Analysis File. The gift provides a catalog guide to NBC programming from 1939 to 1985 , including 18,000 NBC programs previously given to the Library in 1986 . The file contains more than 632,000 cards with detailed information on each broadcast, including air date and time, story line, and credits.

- The New York State Library, Albany, has received the papers of Rousseau Flower, an invertebrate paleontologist whose special research into Devonian and Ordovician geology and paleontology at the New Mexico Bureau of Mines and Mineral Resources was nationally recognized. There are 22 boxes of correspondence as well as student notebooks from his years at Cornell University. 